\title{
PRIMERJAVA 2D IN 3D GIS MODELA PRI NAČRTOVANJU ŠOLSKIH PREVOZOV
}

\author{
dr. Klemen Prah, dr.Tomaž Kramberger, \\ dr. Dejan Dragan \\ Fakulteta za logistiko, Univerza v Mariboru, \\ Mariborska cesta 7, SI-3000 Celje \\ e-pošta:klemen.prah@um.si, tomaz.kramberger@um.si,dejan.dragan@um.si
}

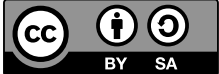

Izvirni znanstveni članek

COBISS 1.01

DOI: $10.4312 /$ dela.49.61-74

\section{Izvleček}

V članku primerjamo dvodimezionalni (2D) in tridimenzionalni (3D) model usmerjanja šolskih vozil na primeru občine Laško z vidika dolžine prepeljanih kilometrov in porabljenega potovalnega časa. Pri 3D modelu je cestna mreža položena preko digitalnega modela višin 12,5 metrov, kar daje modelu večjo podobnost $\mathrm{z}$ realnostjo. Za uspešno rešitev je v obeh modelih potrebnih 23 kombijev. V 3D modelu je dolžina vseh opravljenih poti za 45,58 kilometrov večja kot v 2D modelu, skupni potovalni čas pa daljši za 1 uro in 14 minut. Ugotovljena razlika je pomembna pri odločanju za izbiro enega ali drugega modela pri reševanju problemov usmerjanja šolskih vozil.

Ključne besede: geografski informacijski sistemi, problem usmerjanja šolskih vozil, dvodimenzionalni model transportne mreže, tridimenzionalni model transportne mreže, občina Laško

\section{COMPARISON OF 2D AND 3D GIS MODEL FOR SCHOOL VEHICLES ROUTING}

\begin{abstract}
In the article we compare the two-dimensional (2D) and the three-dimensional (3D) model of school vehicles routing on the example of the Laško municipality. We compare both models in terms of the length of kilometres travelled and the travel time spent. In the $3 \mathrm{D}$ model, the road network is laid over a digital model of elevation cell size 12.5 times 12.5 meters, which gives the model more resemblance to reality. For a successful solution, 23 vans are needed in each model. In the $3 \mathrm{D}$ model, the length of all routes is 45.58 kilometres higher than in the 2D model, while the total travel time is longer for 1 hour and 14 minutes. The difference found is important when deciding on the choice of one or another model in solving problems of school vehicles routing.
\end{abstract}

Keywords: geographic information systems, school-bus routing problem, two-dimensional model of transportation network, three-dimensional model of transportation network, Laško municipality 


\section{UVOD}

Načrtovanje usmerjanja šolskih vozil je pomembno vsaj s treh vidikov: ekonomskega, okoljskega in socialnega. Številne šole in občine se soočajo z velikimi finančnimi stroški, ki so povezani s šolskimi prevozi. Ti mnogokrat niso optimalno urejeni. Postajališča niso optimalno razporejena in poti niso optimalno izpeljane, zaradi česar nastajajo dodatni kilometri, ki terjajo več vozil. Vse to vpliva na povečane količine izpušnih plinov, eventuelno pa tudi na daljši potovalni čas, ki ga učenci prebijejo v vozilih.

Pri optimizaciji šolskih prevozov si lahko pomagamo z geografskimi informacijskimi sistemi (GIS-i). Uporaba GIS sistemov je v raziskavah še vedno prevladujoča $\mathrm{v}$ dvodimenzionalni (2D) obliki (Heywood, Cornelius, Carver, 2011) in takšno smo tudi uporabili pri dosedanjih optimizacijah šolskih prevozov (Dragan, Kramberger, Lipičnik, 2011; Dragan in sod., 2011). Pri 2D GIS-ih je transportna mreža, v našem primeru ceste s postajališči, postavljena $\mathrm{v}$ ravnino, zaradi česar se pri optimizaciji poti ne upošteva razgibanosti reliefa. Ker pa je relief pomemben dejavnik, ki vpliva na dostopnost, na dolžino poti, na značilnosti vožnje vozila, kot so hitrost, poraba goriva, emisije ipd., ga je nedvomno smiselno vključiti v optimizacijo poti. Takšen model bi bil tridimenzionalen (3D) in ga v primerjavi z 2D modelom obravnavamo kot bolj realnega.

Cilj raziskave je primerjati 2D in 3D model usmerjanja šolskih vozil z vidika dolžine prepeljanih kilometrov in porabljenega potovalnega časa, pri čemer se osredotočamo na občino Laško. Pri tem upoštevamo postajališča, ki so bila določena že v eni od prejšnjih raziskav (Dragan, Kramberger, Lipičnik, 2011). V kolikor so razlike glede prepeljanih kilometrov in potovalnega časa med obema modeloma občutne, je pri nadaljnjih projektih usmerjanja šolskih vozil smiselno izbrati 3D model, ki bolj realistično obravnava pokrajino.

Namreč, v 3D okolju pot med dvema točkama (A in B) ne poteka več v ravnini, zaradi česar je pot daljša $\left(\mathrm{d}<\mathrm{d}_{\mathrm{n}}\right)$ (slika 1$)$. Predpostavljamo torej, da 3D model usmerjanja šolskih vozil v primerjavi z 2D modelom poda rešitev, kjer je skupna dolžina prepeljanih

Slika 1: Obravnavanje poti med dvema istima točkama A in B v ravnini in v $3 D$ prostoru.

Figure 1: Path between two same points $A$ and $B$ in a plane and $3 D$ space.
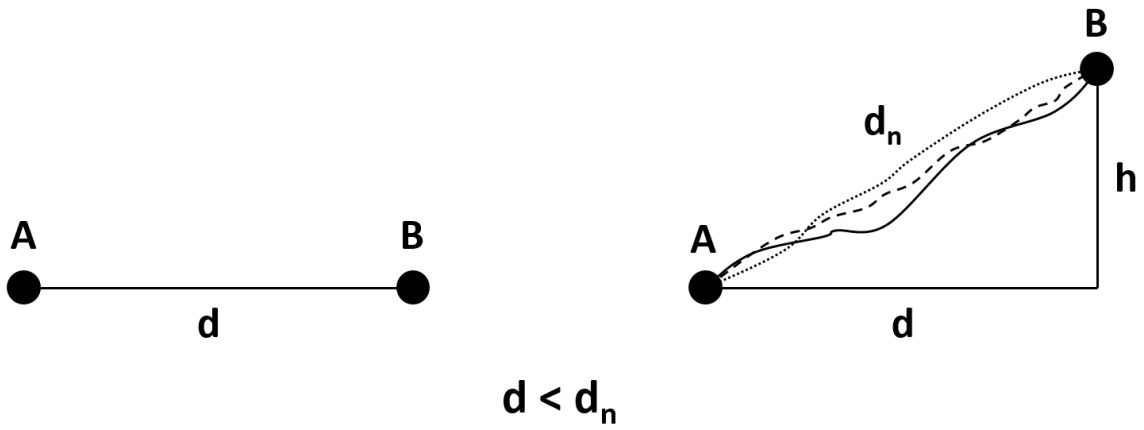
poti večja, skupni potovalni čas pa daljši. Ocenjujemo, da je razlika v obeh rešitvah s stališča ekonomike občutna, če znaša vsaj 3-5\%. Kot namreč kažejo raziskave (npr. Yun 2012; Wood in sod., 2014), že majhen odstotek povečanja naklona posameznih cest poveča ne le število prevoženih kilometrov, pač pa zlasti skupno povprečno porabo goriva vozil. Ta se namreč pri povečanih naklonih cest (npr. za od $4 \%$ do $8 \%$ ) v povprečju skoraj podvoji glede na ceste z neznatnim oz. ničelnim naklonom.

V nadaljevanju je članek organiziran na sledeč način. V poglavju 2 so predstavljene dosedanje raziskave usmerjanja šolskih vozil, predvsem razvoj, ki je vodil do reševanja problema s 3D modelom. V poglavju 3 je predstavljena metodologija raziskovanja, ta pa je v naši raziskavi povezana pretežno z GIS-i. V poglavju 4 na kratko predstavimo tiste značilnosti občine Laško, ki lahko vplivajo na značilnosti transporta. V poglavju 5 uporabimo in testiramo oba modela (2D in 3D model) na primeru občine Laško ter primerjamo rezultate, v poglavju 6 pa podamo nekaj zaključkov.

\section{DOSEDANJE RAZISKAVE}

Obstajajo številni znanstveni članki, ki obravnavajo optimizacijo šolskih prevozov. V enem izmed prvih sta Newton in Thomas (Newton, Thomas, 1974) predstavila model, ki minimizira dvoje - skupni čas, potreben za dokončanje vseh poti, in število poti, potrebnih za servisiranje vseh postajališč, povezanih s šolo.

Tradicionalni problem usmerjanja vozil, angleško imenovan Vehicle Routing Problem (VRP) stremi h generiranju učinkovitih poti za množico vozil z namenom dostave tovora iz zbirnih centrov (t. i. depojev) ali zbiranja tovora v slednjih za množico strank (Laporte, 1992). Kasneje so bile razvite številne različice začetnega problema, ki vsebujejo različne omejitve. Ena od teh različic je problem usmerjanja vozil s časovnimi okni, angleško Vehicle Routing Problem with Time Windows (VRPTW) (Cordeau in sod., 2000). Ta problem imenujemo z drugim izrazom Problem usmerjanja šolskih vozil, angleško School Bus Routing Problem (SBRP). Njegov namen je načrtovati učinkovite urnike za množico šolskih vozil, pri čemer je potrebno učence prepeljati v šolo in iz nje ter pri tem zadostiti različnim omejitvam, kot so maksimalna kapaciteta vozila, maksimalni potovalni čas učenca ter časovne omejitve šole (Park, Kim, 2010). Problem usmerjanja šolskih vozil je možno reševati s petimi koraki: priprava podatkov, določitev avtobusnih postajališč, določitev avtobusnih poti, prilagoditev šolskega zvonca in časovni načrt voženj (Desrosiers in sod., 1986b). Kasneje so bile razvite številne različice Problema usmerjanja šolskih vozil.

Že sredi devetdesetih let prejšnjega stoletja je Pollitt s sodelavci (Pollitt, 1995; Eklund, Kirkby, Pollitt, 1996) razvil pristop usmerjanja vozil, ki temelji na 3D prostorskem informacijskem sistemu. Pristop, ki uporablja ravninsko transportno mrežo, upošteva vrednosti dolžine cestnih segmentov v 3D prostoru, pridobljene na osnovi digitalnega modela višin. Vendar pa so pomanjkljivosti ravninskega modela, kot je na primer nezmožnost križanja dveh povezav brez prisotnosti vozlišča, spodbudile zanimanje za razvoj modela neravninske transportne mreže (Fischer, 2004), ki pa je bil še vedno implementiran v 2D prostoru. Nadaljnji korak je bil narejen, ko je skupina avtorjev (Zhu, Li, Tor, 2008) 
razvila model neravninskega transportnega omrežja v 3D prostoru, ki izboljšuje sposobnost prikaza zapletene transportne strukture ter zagotavlja vključitev večdimenzionalnih podatkov neposredno v model. Po našem mnenju bi prišel takšen model posebej do izraza v urbani regiji, kjer je prisotnih veliko nadvozov in podvozov in kjer morajo potujoči zaradi visokih zgradb opravljati precejšen delež poti pri premiku iz visokega nadstropja v pritličje in obratno.

Naša raziskava je posebna $v$ tem, da primerjamo ravninska $2 \mathrm{D}$ in $3 \mathrm{D}$ modela usmerjanja šolskih vozil. Zanima nas predvsem razlika med obema modeloma glede skupne dolžine vseh prepeljanih poti in posledično skupnega potovalnega časa.

\section{METODE DELA}

Pri delu smo si pomagali z računalniškim programom ArcGIS for Desktop, različico 10.2.2 in s programsko razširitvijo Network Analyst (ESRI, 2014). Slednja zagotavlja orodja za mrežne prostorske analize, s katerimi lahko rešujemo kompleksne probleme usmerjanja.

$\mathrm{V}$ našem primeru sta 2D model in 3D model transportne mreže ravninska in sta postavljena v ravninski koordinatni sistem D48/GK. Cestna mreža pri obeh modelih je predstavljena $\mathrm{z}$ vektorskim podatkovnim slojem in je bila pridobljena od podjetja NAVTEQ (NAVTEQ, 2008a). Opremljena je s številnimi atributi, kot so na primer kategorija ceste, hitrostna kategorija, smer potovanja, prepoved za avtomobile, dolžina cestnega odseka, višinski nivo ceste ipd. Iz podatkovnega sloja za ceste smo ustvarili mrežno podatkovno bazo, sestavljeno iz povezav in vozlišč. Vsaka povezava ima določene lastnosti, opredeljene $\mathrm{z}$ vrednostmi posameznih atributov in je povezana $\mathrm{z}$ dvema vozliščema na svojih krajiščih.

Opredelili smo upoštevanje globalnih zavijanj, kar pomeni, da smo časovno ovrednotili vsako zavijanje, za kar se upošteva vsak prehod med dvema sosednjima povezavama. Pri tem smo uporabili privzete nastavitve (ESRI, 2014), pri katerih se najmanj časa (le 0,5 sekunde) porabi pri vožnji naravnost za prehod s sekundarne ceste na sekundarno cesto, pri čemer se prečka lokalna cesta. Največ časa, in sicer 15 sekund, pa se porabi pri polkrožnem zavoju z lokalne na sekundarno cesto.

Pri opredelitvi načina povezljivosti v modelu cestne mreže smo uporabili povezljivost krajišč, ki določa, da se lahko dve povezavi združita le na sovpadajočem krajišču. Na ta način smo preprečili zavijanja, ki v naravi niso možna, na primer direktni preskok z nadvoza na spodaj speljano cesto.

Za opredeljevanje višinskih nivojev smo v modelu uporabili višinski atribut. Namreč uporabljeni podatkovni sloj cest vsebuje atribut Z-Level, ki opredeljuje relativni vertikalni položaj vsakega vozlišča (NAVTEQ, 2008b). Uporablja se za opredelitev nadvozov in podvozov v omrežju. Enako kot zgoraj omenjen način povezljivosti tudi višinski atribut preprečuje tista zavijanja, ki v naravi niso možna.

V okviru modela smo uporabili posebne atribute, poimenovane Metri, Minute, Hierarhija in Enosmerna cesta. $Z$ atributom Metri smo opredelili dolžino vsake cestne povezave v metrih. $Z$ atributom Minute smo opredelili čas vožnje v minutah za vsako povezavo 
cestnega omrežja. Vrednosti za atribut Minute smo izpeljali iz dveh atributov, in sicer iz atributa Metri in iz atributa, ki opredeljuje povprečno hitrost vožnje za vsako cestno povezavo. Povprečno hitrost vožnje za vsako povezavo smo izpeljali iz obstoječega atributa Hitrostna kategorija, in sicer tako, da smo vzeli najmanjšo vrednost v razponu, ki ga opredeljuje posamezna hitrostna kategorija.

Z atributom Hierarhija smo na osnovi obstoječega atributa za kategorije cest oblikovali tri razrede: primarne ceste, sekundarne ceste in lokalne ceste. Kasneje smo pri transportni mrežni analizi uporabili ta atribut na način, da vgrajeni algoritem, ki rešuje problem usmerjanja množice vozil, teži v prvi vrsti k uporabi primarnih cest, nato sekundarnih in nazadnje lokalnih.

$\mathrm{V}$ našem primeru se 3D model razlikuje od 2D modela $\mathrm{v}$ tem, da je pri prvem podatkovni sloj cestnega omrežja položen preko digitalnega modela višin DMV 12.5 (GURS, 2018). Na ta način smo pridobili realnejše vrednosti za dolžino vseh cestnih odsekov, ki tvorijo model transportne mreže. Tako ima primer cestnega odseka, ki je prikazan na karti (slika 2) in je položen preko digitalnega modela višin, dolžino 1444,22 m, medtem ko v 2D modelu ta znaša le 1405,77 m. Razlika je torej 38,45 m. Graf prikazuje pogled na izbrani cestni odsek s strani, pri čemer vodoravna os prikazuje dolžino, navpična os pa nadmorsko višino (slika 3). Vidimo, da pot ni ravna črta, ampak krivulja, katere potek je odvisen od reliefa.

Slika 2: Izbrani cestni odsek položen preko digitalnega modela višin.

Figure 2: Selected road section placed on the digital height model.

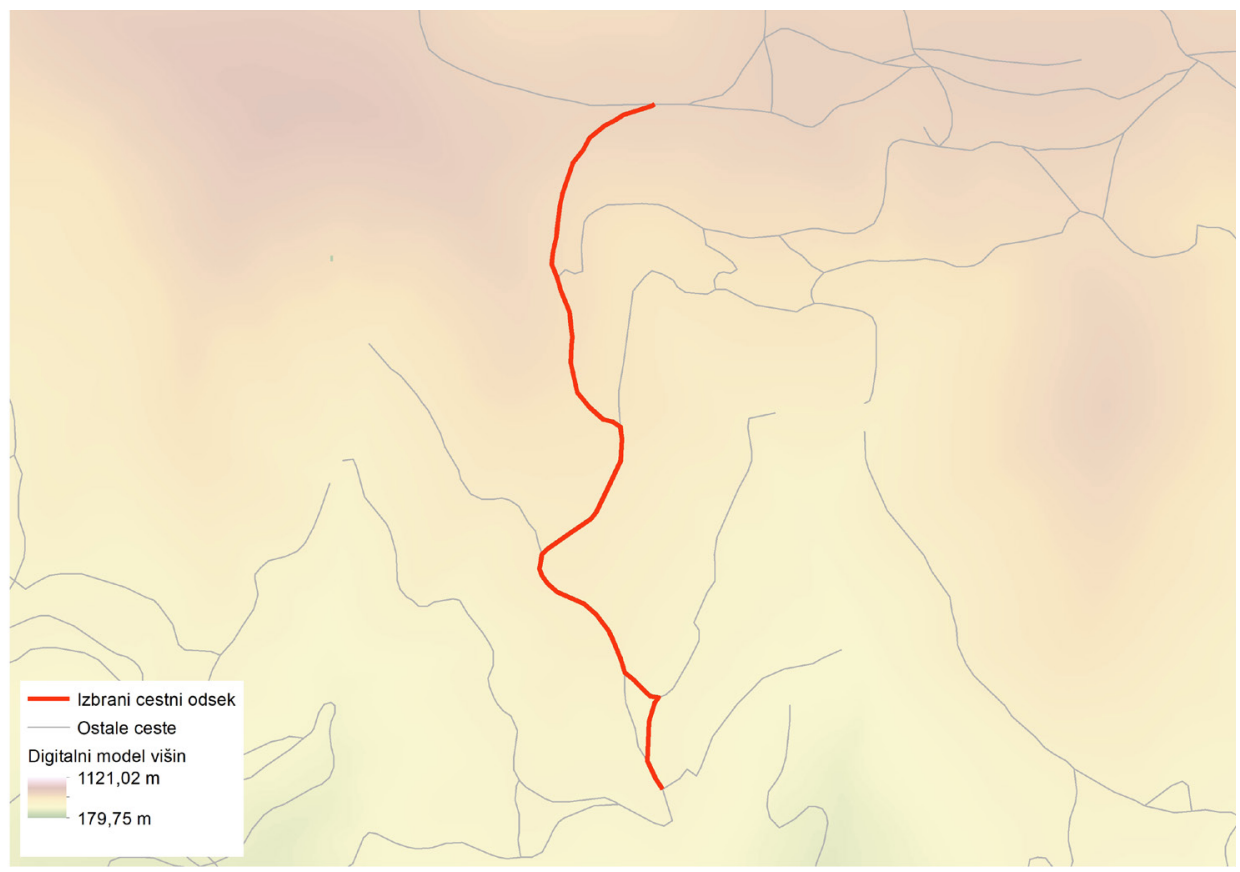


Slika 3: Pogled na izbrani cestni odsek s strani, pri čemer vodoravna os prikazuje dolžino, navpična os pa nadmorsko višino odseka.

Figure 3: View at the selected road section from the side (horizontal axis shows length, vertical axis shows altitude of the section)

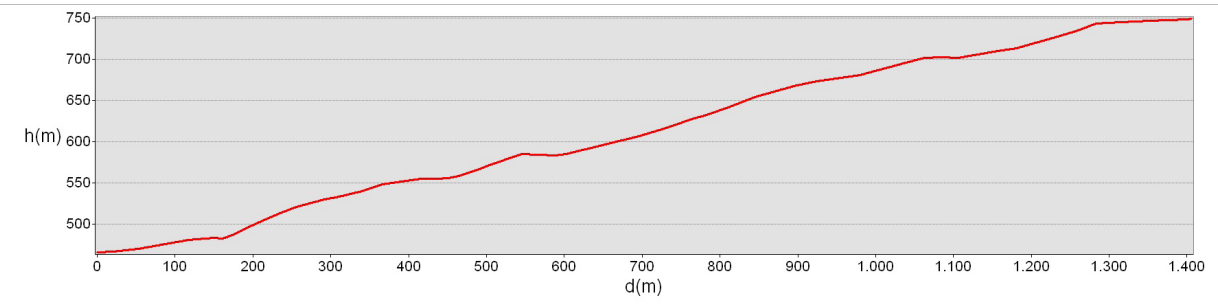

Reševanja problema usmerjanja šolskih vozil smo se lotili po zgoraj omenjenem zgledu SBRP. V okviru priprave podatkov smo ustvarili transportno mrežno podatkovno bazo, kot opisano zgoraj. Poleg tega smo pripravili podatke o učencih, šolah in vozilih. Podatki o učencih obsegajo domač naslov in ustrezno šolo. Podatki o šolah obsegajo informacijo o lokaciji šol, o najzgodnejšem in najkasnejšem možnem prihodu učencev v šolo ter o maksimalnem času, ki ga učenec lahko preživi v avtobusu. Podatki o vozilih obsegajo startno lokacijo vozila in vrsto vozila, pri čemer je najpomembnejša kapaciteta vozila.

Kot omenjeno, avtobusnih postajališč nismo določili na novo, ampak smo uporabili postajališča, določena v predhodni raziskavi (Dragan, Kramberger, Lipičnik, 2011). Ker je občina Laško pretežno ruralna, bi morda celo pričakovali, da bodo vozila pobirala učence kar na njihovih domovih (Park, Kim, 2010), vendar bi to pomenilo daljše poti vozil in daljše potovalne čase ter posledično višje finančne stroške. Določitev poti vozil temelji na zgoraj omenjenem problemu VRPTW (Desrosiers in sod., 1986a), ki je nadgradnja problema trgovskega potnika (Lawler in sod., 1985).

Prilagoditev šolskega zvonca pomeni določitev začetka in konca pouka. Ker se v raziskavi osredotočamo le na prevoz učencev v šolo, je pomemben le čas začetka pouka. Časovni načrt voženj predstavlja končno rešitev problema. Za vsako vozilo dobimo natančen startni in končni čas ter zaporedje poti.

$\mathrm{V}$ raziskavi je problem usmerjanja šolskih vozil v obeh modelih - 2D in 3D - zasnovan enako. To pomeni, da so podatki o učencih, šolah, vozilih, avtobusnih postajališčih in začetku pouka enaki v obeh modelih. Razlika je le v tem, da je v 3D modelu transportno omrežje postavljeno v tridimenzionalni prostor, ki ga ponazarja digitalni model višin DMV 12.5.

Namen primerjave obeh modelov je ponuditi informacijo, v kolikšni meri se razlikujejo rezultati izvedenega postopka usmerjanja šolskih vozil med obema modeloma. 3D model smatramo kot realnejši, 2D model pa kot enostavnejši za pripravo in za uporabo in s tem lažje dostopen uporabnikom. S ponujenimi informacijami se bodo organizatorji šolskih prevozov morebiti lažje odločili za uporabo enega od modelov. Lažje bodo presodili, ali je smiselno vložiti več truda in časa (pridobitev in priprava podatkov DMV, uporaba GIS orodij za tridimenzionalne mrežne analize) za realnejšo rešitev, ali pa se zadovoljiti z nekoliko enostavnejšo, vendar še vedno dobro rešitvijo v 2D modelu. 


\section{PREDSTAVITEV OBRAVNAVANEGA OBMOČJA}

$\mathrm{V}$ raziskavi se osredotočamo na občino Laško, ki spada v Posavsko hribovje. Zanj je značilna močna razčlenjenost površja z dolinami in grapami (Hrvatin, 2001). S 198 km² površine in približno 13.300 prebivalci spada občina med srednje velike slovenske občine. Gostota prebivalstva znaša 67 prebivalcev na $\mathrm{km}^{2}$, kar je le 65,5\% slovenskega povprečja (Laško - Slovenske regije in občine v številkah, 2014).

Najnižja točka v občini se nahaja na 190 metrih, najvišja pa na 984 metrih nadmorske višine (GURS, 2018). V dolini ob spodnjem toku reke Savinje je osrednji kraj Laško, gručasto mestno naselje. Za višje predele v občini so značilna razložena naselja in samotne domačije (Hrvatin, 2001).

Učenci v občini Laško obiskujejo 11 šol. Od tega sta šoli Primoža Trubarja v Laškem in Antona Aškerca v Rimskih Toplicah matični šoli, ostale po so podružnične. Najnižje ležeča šola v občini je na nadmorski višini 215 metrov - to je podružnična šola v Zidanem mostu, najvišje ležeča pa na 570 metrov - podružnična šola Šentrupert. Štiri šole v občini Laško, ki se nahajajo v dolini Savinje, ležijo na nadmorski višini do 300 metrov, tri šole med 300 in 400 metrov, dve šoli med 400 in 500 metrov ter dve šoli nad 500 metrov.

Zaradi reliefne razčlenjenosti je Posavsko hribovje težko prehodno (Hrvatin, 2001). Občina Laško ima eno najbolj razvejanih občinskih cestnih omrežij v državi, saj pripada na prebivalca občine kar 30 m cest, slovensko povprečje pa je 7 m (Kovač, 2006). Veliko število naselij, razgibanost območja občine, konfiguracija terena, slaba poseljenost, veliko število posameznih cestnih odsekov, nezadosten nivo vzdrževanja in slaba kvaliteta gradnje imajo za posledico slabšanje stanja občinske cestne infrastrukture (Salobir, 2005). JP Komunala Laško izvaja redno letno in zimsko vzdrževanje lokalnih cest, kjer se odvija organiziran prevoz otrok v šolo (Salobir, 2005).

\section{APLIKACIJA PREDLAGANIH MODELOV}

V raziskavo smo zajeli tistih 554 učencev, za katere smo s strani Občine Laško dobili podatek, da se v šolo vozijo s šolskim prevozom. Učenci so razpršeni po vsej občini, od tega jih 19 živi na nadmorski višini med 600 in 715 metri. Postavili smo časovni okvir, da lahko učenci prispejo v šolo najbolj zgodaj ob 6. uri in 40 minut, najkasneje pa ob 8. uri in 10 minut. Učenec lahko preživi v vozilu maksimalno 60 minut.

Načrtovali smo, da vse učence vozijo v šolo kombiji, pri čemer lahko vsak kombi pelje največ osem učencev naenkrat. Kombiji začnejo voziti s treh različnih lokacij, kjer so parkirani. Za vkrcanje oziroma izkrcanje enega učenca v vozilo oziroma iz vozila smo predvideli 8 sekund časa.

Dolžina vseh cest v občini Laško znaša v 2D modelu 960,54 kilometrov, v 3D modelu pa 970,88 kilometrov. V slednjem modelu je torej dolžina cest večja za 10,34 kilometrov oziroma za $1,07 \%$.

Za uspešno rešitev problema usmerjanja šolskih vozil v občini Laško je potrebnih 23 kombijev. Rešitev v 2D modelu (slika 4) nam da rezultat za skupno prepotovano razdaljo vseh poti 1349,59 kilometrov, za kar je potrebnih 41 ur in 37 minut potovalnega časa. Rešitev v 
Slika 4: Prikaz rešitve problema usmerjanja šolskih vozil, dobljene v $2 D$ modelu.

Figure 4: Solution of the problem of routing school vehicles as obtained by $2 D$ model.

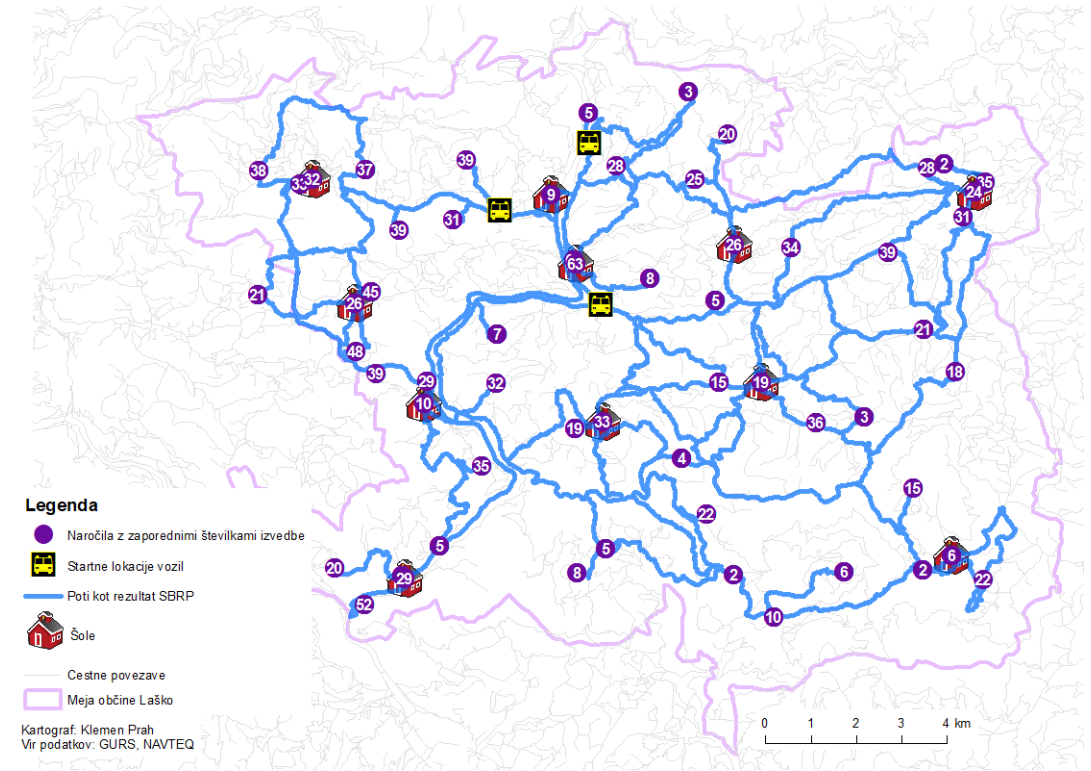

Slika 5: Prikaz rešitve problema usmerjanja šolskih vozil, dobljene v 3D modelu.

Figure 5: Solution of the problem of routing school vehicles as obtained by $3 D$ model.

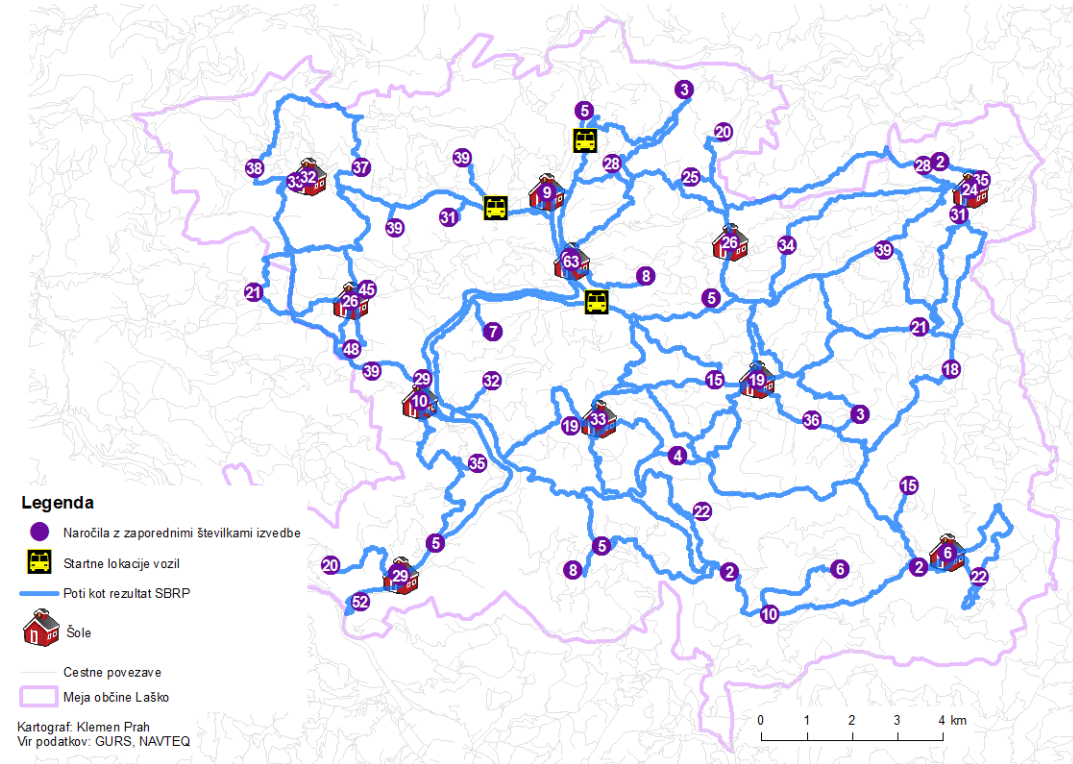


3D modelu (slika 5) pa nam da rezultat za skupno prepotovano razdaljo vseh poti 1395,17 kilometrov, za kar je potrebnih 42 ur in 51 minut potovalnega časa. V 3D modelu potrebujemo torej za rešitev istega problema usmerjanja šolskih vozil 1 uro in 14 minut več časa (slika 7) oziroma znaša prepotovana razdalja vseh poti za 45,58 kilometrov več (slika 6).

Slika 6: Primerjava skupne prepotovane razdalje $v 2 D$ in $3 D$ modelu.

Figure 6: Comparison of total travel distance in $2 D$ and $3 D$ models.

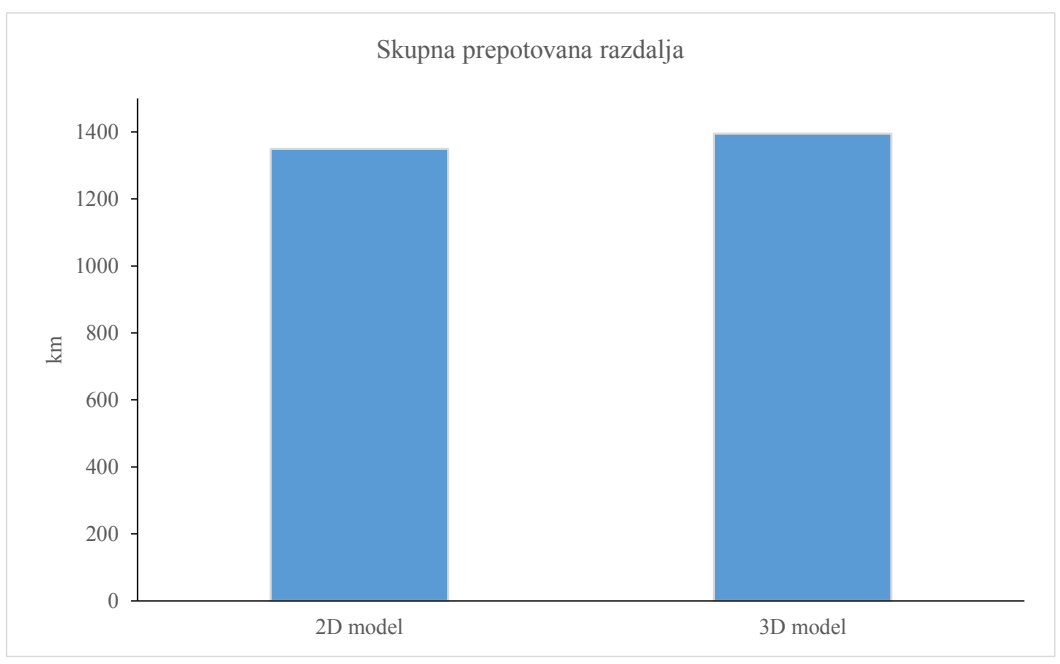

Slika 7: Primerjava skupnega potovalnega časa v 2D in 3D modelu.

Figure 7: Comparison of total travel time in $2 D$ and $3 D$ models.

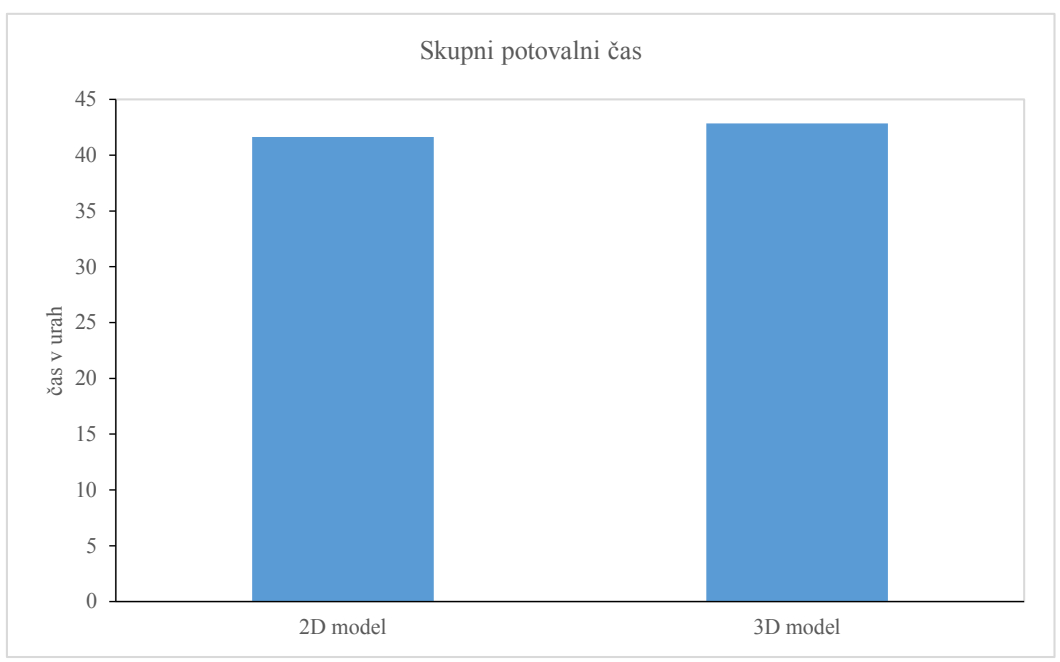




\section{ZAKLJUČEK}

$\mathrm{V}$ članku smo primerjali reševanje problema usmerjanja šolskih vozil v občini Laško z $2 \mathrm{D}$ in $3 \mathrm{D}$ modelom. V 3D modelu je cestna mreža položena preko digitalnega modela višin, kar daje modelu večjo podobnost $\mathrm{z}$ realnim svetom. V 3D modelu je dolžina vseh opravljenih poti za 45,58 kilometrov oziroma 3,27 \% večja kot v 2D modelu. Temu ustrezno je v 3D modelu daljši skupni potovalni čas, in sicer za 1 uro in 14 minut oziroma za 2,9 \%. Razlika med 2D in 3D modelom ni tolikšna, da bi morali pri 3D modelu uvesti dodatni kombi.

Razliko med obema rešitvama lahko ocenimo tudi s finančnega vidika, pri čemer je treba upoštevati, da se višina stroška na kilometer prevožene razdalje s šolskim kombijem razlikuje od primera do primera oziroma od občine do občine. Vzemimo, da stane 1 prevožen kilometer s kombijem, ki ima kapaciteto 8+1 potnikov, 3 EUR (vključno z ddv) (Stopar, 2017). Potemtakem nanese dodatnih 45,58 kilometrov 136,74 EUR stroškov na dan. V enem mesecu to pomeni 2.734,8 EUR, v enem letu pa 27.348 EUR stroškov. S finančnega vidika je torej razlika med obema rešitvama (2D in $3 \mathrm{D})$ pomembna. Ta razlika postane še bolj občutna, če upoštevamo dejstvo, da se že pri rahlo povečanih naklonih cest (3D primer) poraba goriva $\mathrm{v}$ povprečju občutno poveča ali celo podvoji glede na ceste $\mathrm{z}$ neznatnim oz. ničelnim naklonom (2D primer).

$\mathrm{Na}$ kakšen način bi bilo smiselno nadaljevati z raziskavo oz. jo nadgraditi? Ker pride 3D model posebej do izraza na reliefno razgibanih območjih, ga smatramo za pomembnejšega pri načrtovanju šolskih prevozov v reliefno razgibanih občinah. Menimo pa, da bi bilo smiselno narediti primerjavo med 2D in 3D modelom tudi v kateri izmed ravninskih ali mestnih občin.

V članku omenjamo, da je možno problem usmerjanja šolskih vozil reševati celovito po principu SBRP, ki sestoji iz petih podproblemov. Menimo, da bi bilo smiselno 3D pristop uvesti pri vseh podproblemih, kjer je to možno. Še posebej pa bi bilo smiselno na osnovi 3D prostora določili optimalne lokacije postajališč.

Korak naprej bi pomenila tudi uporaba neravninskega 3D modela transportne mreže, saj bi ta še izpopolnil prikaz transportne strukture ter omogočil vključitev večdimenzionalnih podatkov neposredno v model. Vendar menimo, da je neravninski model pomembnejši na urbanih območjih, kjer je veliko nadvozov in podvozov ter visokih zgradb, pri katerih predstavlja znaten del poti premik iz visokega nadstropja v pritličje in obratno.

\section{Literatura in viri}

Cordeau, J. F., Desaulniers, G., Desrosiers, J., Solomon, M. M., Soumis, F., 2000. The VRP with time windows. Les Cahiers du GERAD, G-99-13. URL: https:/www.gerad.ca/en/papers/G-99-13 (citirano 26. 6. 2018).

Desrosiers, J., Soumis, F., Desrochers, M., Sauvé, M., 1986a. Vehicle routing and scheduling with time windows. V: Gallo, G., Sandi, C. (ur.). Netflow at Pisa. Mathematical Programming Studies, 26, str. 249-251. Springer, Berlin, Heidelberg. DOI: 10.1007/ BFb0121107. 
Desrosiers, J., Soumis, F., Desrochers, M., SauveGerad, M., 1986b. Methods for routing with time windows. European Journal of Operational Research, 23, str. 236-245. DOI: 10.1016/0377-2217(86)90243-2.

Dragan, D., Kramberger, T., Lipičnik, M., 2011. Monte Carlo simulation-based approach to optimal bus stops allocation in the Municipality of Laško. PROMET - Traffic\&Transportation, 23, str. 265-278. DOI: 10.7307/ptt.v23i4.129.

Dragan, D., Kramberger, T., Lisec, A., Intihar, M., Prah, K., 2011. Using GIS for the optimization of pupils transportation: The case of Laško Municipality. Logistics \& sustainable transport, 2, str. 35-51.

Eklund, P., Kirkby, S., Pollitt, S., 1996. A dynamic multi-source Dijkstra's algorithm for vehicle routing. V: Narasimhan, V. L., Jain, L. C. (ur.). Australian-New Zealand Conference on Intelligent Information Systems. Adelaide, str. 329-333. DOI: 10.1109/ ANZIIS.1996.573976.

ESRI. 2014. ArcGIS for Desktop 10.2.2. Redlands, Environmental Systems Research Institute.

Fischer, M., 2004. GIS and network analysis. ERSA conference papers ersa03p433, str. 391-408. URL: https://ideas.repec.org/p/wiw/wiwrsa/ersa03p433.html (citirano 20. 5. 2018).

GURS. Digitalni modeli višin. Geodetska uprava RS. URL: http://www.e-prostor.gov.si/ zbirke-prostorskih-podatkov/topografski-in-kartografski-podatki/digitalni-model-vi$\sin /$ (citirano 19. 5. 2018).

Heywood, I., Cornelius, S., Carver, S., 2011. An introduction to geographical information systems. 4th ed. Harlow, Pearson, 446 str.

Hrvatin, M., 2001. Posavsko hribovje. V: Perko, D., Orožen Adamič, M. (ur.). Slovenija - pokrajine in ljudje. Ljubljana, Mladinska knjiga, str. 178-190.

Kovač, P., 2006. Geografija občine Laško. Diplomsko delo. Ljubljana, Filozofska fakulteta, Oddelek za geografijo, 185 str. URL: https://repozitorij.uni-lj.si/IzpisGradiva. php?id=17089\&lang=slv\&prip=dkum:19878:d5 (citirano 31. 7. 2018).

Laporte, G., 1992. The vehicle routing problem: An overview of exact and approximate algorithms. European Journal of Operational Research, 59, str. 345-358. DOI: 10.1016/0377-2217(92)90192-C.

Laško - Slovenske regije in občine v številkah. 2014. Ljubljana, Statistični urad Republike Slovenije. URL: http://www.stat.si/obcine/sl/2014/Municip/Index/78 (citirano 1. 8. 2018).

Lawler, E. L., Lenstra, J. K., Rinnooy Kan, A. H. G., Shmoys, D. B. (ur.), 1985. The traveling salesman problem. Chichester, John Wiley \& Sons, 463 str.

NAVTEQ. 2008a. NAVTEQ NAVSTREETS street data. Chicago.

NAVTEQ. 2008b. NAVTEQ's NAVSTREETS street data, reference manual v 3.0. Chicago.

Newton, R. M., Thomas, W. H., 1974. Bus routing in a multi-school system. Computers \& Operations Research, 1, str. 213-222. DOI: 10.1016/0305-0548(74)90047-1.

Park, J., Kim, B. I., 2010. The school bus routing problem: A review. European Journal of Operational Research, 202, str. 311-319. DOI: 10.1016/j.ejor.2009.05.017. 
Pollitt, S., 1995. A 3-D spatial information system for emergency routing in Okayama City. Diplomsko delo. Adelaide, Department of Computer Science, 81 str.

Salobir, M., 2005. Vzdrževanje in investicijska dela na občinskih cestah. V: Klepec, J. (ur.). Bilten občine Laško. Občina Laško, str. 18-19.

Stopar, A., 2017. Planiranje razvoza otrok na primeru osnovne šole Poljčane. Diplomsko delo. Celje, Fakulteta za logistiko, 103 str. URL: https://dk.um.si/IzpisGradiva. php?id=67184\&lang=slv (citirano 27. 7. 2018).

Yun, J., 2012. Study of the driving cycle for heavy duty trucks in hilly terrain and its effect on calculated emissions, and comparison of two mobile emission models. PhD dissertation. University of Tennessee.

Wood, E., Burton, E., Duran, A., Gonder, J., 2014. Contribution of road grade to the energy use of modern automobiles across large datasets of real-world drive cycles: Preprint. United States. DOI: 10.4271/2014-01-1789.

Zhu, Q., Li, Y., Tor, Y. K., 2008. Multidimensional and dynamic vehicle emergency routing algorithm based on 3D GIS. V: Zlatanova, S., Li, J. (ur.). Geospatial Information Technology for Emergency Response. London, CRC Press. URL: https:/www.taylorfrancis.com/books/e/9780203928813/chapters/10.4324\%2F9780203928813-18 (citirano 19. 6. 2018).

\section{COMPARISON OF 2D AND 3D GIS MODEL FOR SCHOOL VEHI- CLES ROUTING}

\section{Summary}

The well-known school bus routing problem (SBRP) still represents a big challenge for the researchers in the field of operations research and optimal designing of the adequate school transport. The planning of the routing of school vehicles is important at least from three aspects: economic, environmental and social. Many schools and municipalities are faced with high financial costs associated with school transportation of pupils. The latter is often not optimally organized. The bus stops are not optimally settled, and the routes are not optimally designed, resulting in unnecessary additional kilometers that require more vehicles. All of this affects the increased exhaust emissions, and possibly also the longer travel time that pupils must spend traveling in the vehicles.

When optimizing a school transport, the geographic information systems (GISs) might be of essential matter. The use of GIS systems is still predominant in the twodimensional (2D) form without taking into account the relief and terrain elevation. However, the relief is an important factor considering accessibility, the length of the journey, the characteristics of driving of the vehicles, such as speed, fuel consumption, and emissions, and so on. Thus, it is certainly worthwhile to include a third dimension in the vehicles' routing optimization. Such a model would be threedimensional (3D) GIS model and might be treated as a more realistic compared to its 2D model counterpart. 
The research reported in this paper is a logical continuation of our previous work regarding the optimization of school transport (Dragan, Kramberger, Lipičnik, 2011; Dragan et al., 2011). In the former research applied with the 2D GIS system, the transport network, the corresponding roads, and calculated bus stops, were positioned in the pure plane, which means that optimization of the routes did not take into account the diversity of the terrain.

The research aims to compare the 2D and 3D model of the routing of school vehicles in terms of the length of total kilometers traveled and the travel time spent, focusing on the municipality of Laško. We take into account the optimal allocation of the bus stops, which were computed in one of our previous studies (Dragan, Kramberger, Lipičnik, 2011) by means of Monte Carlo simulation based optimization procedure. The main motive for the research was to verify whether there are any significant differences in total mileage and travel time between the 2D and 3D models. If this assumption would have been confirmed, it is logical to choose a 3D models instead of 2D models in the future projects related to the optimization of school transport, since they more realistically deal with the diverse landscape and hilly terrain. We, therefore, assume that the 3D model, compared to the 2D model, provides a solution where the total length of the traveled routes is greater and the total travel time is longer.

We estimate that the difference in both solutions is significant from the economic point of view if it takes at least 3 to $5 \%$. Specifically, according to a research of some other authors (e. g., Yun 2012; Wood et al., 2014), a small percentage increase in the inclination of individual roads increases not only the number of kilometers traveled but in particular the overall average fuel consumption (FC) of vehicles. Namely, in these studies, it was shown that increased road slopes (e. g., by $4 \%$ to $8 \%$ ), on average, cause almost doubled FC with respect to roads with only a slight or zero slope.

The research was conducted by means of the ArcGIS for Desktop, version 10.2.2 and the Network Analyst software extension (ESRI, 2014). The latter provides tools for spatial network analysis, which can solve complex routing problems. The road network for both models is represented by a Vector Data Layer and obtained from NAVTEQ (NAVTEQ, 2008a). It is equipped with a number of attributes such as road category, speed category, the direction of travel, road section length, altitude road level, etc. From the data layer for roads, we have created a network database consisting of links and nodes.

In order to define altitude levels, we have used a height attribute in the model. Namely, the used data road layer contains the Z-Level attribute, which defines the relative vertical position of each node (NAVTEQ, 2008b). It is used to define overpasses and underpasses in the network. With the attribute of Hierarchy, three classes have been developed based on the existing attribute for road categories: primary roads, secondary roads, and local roads. Later, in the transport network analysis, this attribute was used in such a way that the built-in algorithm that solves the problem of routing the vehicles is primarily aimed at the use of primary roads, then secondary and, finally, local ones.

In our case, the 3D model differs from the 2D model in that the first data layer of the road network is laid over the digital height model of elevation cell size 12.5 times 12.5 meters. In this way, we have obtained more realistic values for the length of all road 
sections that form the transport network model. Consequently, the routes are not straight lines anymore, but the curves, for which the course depends on the relief.

The research has covered 554 pupils dispersed throughout the municipality, who were traveling to their schools by using school transport. For the successful solution of the problem of school vehicles' routing, 23 vans had been needed. The solution of the 2D model gives the result 1349.59 kilometers for a total distance traveled, which takes 41 hours and 37 minutes of travel time. Conversely, the solution of the 3D model gives the result 1395.17 kilometers for a total distance traveled, which takes 42 hours and 51 minutes of travel time. In the 3D model, we, therefore, need 1 hour and 14 minutes more time $(2.9 \%)$, or the distance traveled by 45.58 kilometers $(3.27 \%)$ more to solve the same problem.

The difference between the two solutions can also be assessed from a financial point of view representing the annual amount of EUR 27.348 more costs when a 3D solution is considered. This difference becomes even more significant if we take into account the fact that, at slightly increased road slopes (3D case), the fuel consumption is actually significantly bigger, i.e., maybe even doubled with respect to roads with a slight or zero slope (2D case).

(Translated by the authors) 